Laser fusion misses targets

\section{Washlngton}

LASER-DRIVEN fusion research has not progressed as quickly as hoped because of technical difficulties, funding shortfalls and problems with one small private contractor, the US Department of Energy (DOE) recently told federal investigators.

As part of an investigation completed last month by the US General Accounting Office (GAO), DOE officials revealed that the US inertial-confinement fusion experiments have turned out to be more difficult than anticipated, putting parts of the programme as much as two years behind schedule. The officials blame many of the delays on "unsatisfactory" performance by KMS Fusion, a Michiganbased private contractor that made parts for the laboratories.

DOE officials also said that KMS lobbied Congress to give it more money than DOE had requested, thus leaving less for other US fusion laboratories. Almost all the DOE laboratories working on inertialconfinement fusion have slipped behind schedule, GAO says. For example, Los Alamos National Laboratory completed only about half of its $1987-89$ objectives on time, because its experiments turned out to be unexpectedly complicated and because KMS was late in delivering target components. Sandia National Laboratory, which is researching particle-beamdriven fusion, is one to two years behind schedule because of difficulty in developing a source of lithium ions for its particle beam. Sandia officials also blame KMS for a congressionally mandated $\$ 1.9$ million reduction in their budget last year. Congress shifted a total of $\$ 3.1$ million from the DOE labs to KMS in 1989 - a year ROYAL SOCIETY

\section{Atiyah for president}

\section{London}

THE Royal Society's Council has chosen Sir Michael Atiyah, a mathematical physicist, as its preferred candidate to replace Sir George Porter as the society's president

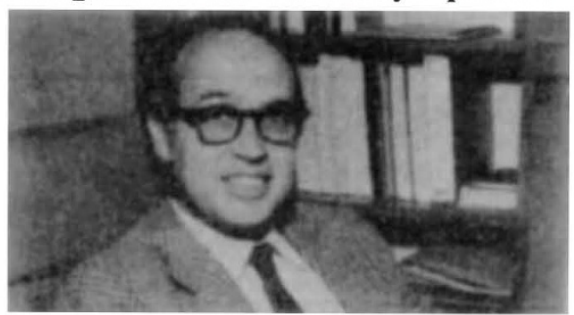

from 30 November. In the past, the council's candidate has always later won the approval of the fellows who choose the president in an election. Atiyah is a Royal Society research professor at the University of Oxford, and president-elect of Trinity College, Cambridge.

Peter Aldhous after the company had donated nearly $\$ 17,000$ to the re-election campaigns of 18 representatives.

According to GAO, its investigation was precipitated by DOE's complaint that KMS had "not met program expectations". Largely because the agency had asked it to abandon much of its own research in favour of supporting efforts at the national laboratories, KMS had trouble "transitioning", GAO found. "Everyone else in the program gets to set their own objectives. We got ours set by the national labs," says KMS president Patrick Long. The DOE national laboratories claim that KMS is "adept at winning additional funding recommendations from the Congress at the expense of the DOE laboratories", GAO reports. "This has led to complaints from the DOE national laboratories that some of their experiments had to be delayed and objectives postponed." DOE programme director Sheldon Kahalis declined to comment on the report.
In the past decade, the KMS political action committee has contributed nearly $\$ 64,000$ to congressional election campaigns, according to the Federal Election Commission, an unusually active lobbying effort for such a small laboratory. But as a private company, "that is our prerogative", says Long. He also points out that KMS invested $\$ 30$ million in research that led to a patent for inertial-confinement fusion. Citing laws that allow the government to annex technology for national security, "DOE took a royalty-free licence", Long says. Any congressional largesse reflects a sense that the company is rightfully entitled to proceeds from the invention, he says. "What kind of annual return should you get on an investment of $\$ 30$ million? The most KMS has ever earned is $\$ 1.2$ million [a year]." Although KMS has performed better recently, DOE plans to open the competition for the KMS contract to other companies later this year. In its 1991 budget proposal, DOE has cut its request for KMS by 45 per cent to $\$ 10$ million, and asked the company to concentrate only on target fabrication.

HUMAN FRONTIERS PROGRAMME

\title{
Grant winners announced
}

\section{Tokyo \& London}

TWENTY-NINE international teams of scientists were last week awarded the first grants for research on the brain and molecular biology under Japan's Human Frontier Science Programme. The successful teams were chosen from more than 200 applications. A greater number of applications is expected next year and the programme's budget will have to be increased drastically to maintain even the present level of awards.

The grants awarded last week range from $\$ 150,000$ to $\$ 400,000$ a year and are to run for three years. Teams led by Japanese won the most grants (9), followed by teams headed by US (8), British (5) and French (3) scientists. The distribution of nationalities fairly closely reflects the number of applicants from each country (see Nature 343, 684; 1990) and should help dispel any doubts that the screening process is fair (see Nature 344, $479 ; 1990)$.

One of the two biggest grants of $\$ 400,000$ a year goes to a team from the United States, West Germany and Japan led by Fuyuhiko Inagaki of Tokyo Metropolitan Institute of Medical Science. The team will try to elucidate the molecular mechanisms of hormone-receptor interaction and signal transduction. The second $\$ 400,000$ grant goes to a United States-Japan team led by Yasuhiro Anraku of Tokyo University which will investigate the molecular mechanics of electron transport-coupled phosphoryla- tion. A team from Sweden and France led by Jacques Mallet of CNRS receives $\$ 385,000$ to examine geneticallyengineered cells producing neurotransmitters.

But while the grant money goes to a wide selection of countries, funds for Frontier postdoctoral fellowships will end up largely in the United States. More than half (45) of the 80 successful fellowship applicants have chosen to go there. Twenty-two will go to European countries, and only three to Japan.

A total of $\$ 12$ million has been spent on this year's awards, with Japan providing $\$ 11$ million and France $\$ 1$ million. Frontier organizers expect more applications next year and some money from this year's Japanese budget of $\mathrm{Y} 2,400$ million ( $\$ 15$ million) will be held over for next year.

Italy, whose scientists did not fare very well in last week's awards, will contribute 1,000 million lira ( $\$ 0.8$ million) next year and some of the money will be used to publicize the programme in Italy. Switzerland, Sweden and Australia have offered to contribute small sums if they are allowed to join (a decision on membership of non-summit nations is expected this month). Japan's budget for the programme in 1990 has been increased 34 per cent over last year to Y3,200 million ( $\$ 20$ million). If the number of awards is to be increased to cope with the anticipated increase in number of applications the programme will need more funds to cope.

David Swinbanks \& Peter Aldhous 